\section{FOUNDATION DENTISTS GATHER IN YORKSHIRE}

Over 200 guests attended this year's British Dental Association (BDA) Best Practice Day at Pinderfields Hospital, Wakefield. Organised by the Yorkshire Deanery for its Foundation Training programme, the event provided an opportunity for local dentists to network and showcase the ideas they have implemented in practice over the past year.

Seventy-six DF1 trainees from across the region were asked to collaborate with their trainers in order to prepare a project which helped to improve the care provided by their practice. The issues tackled ranged from working innovatively with local communities to educate them on oral health, creating learning tools for dental professionals, and helping patients become more aware of their role in treatment.
Following the presentations, participants were invited to vote for a winner in their sub-groups, with the participants in first place going on to the grand final. The overall winners were Marianne Henien and Oliver Pierce of the Hull scheme, for their project on educating primary school children on dental decay.

The UK Committee of Postgraduate Dental Deans and Directors (COPDEND) has agreed that since dental foundation training is now officially defined as being of a year's duration, training posts that follow on from completion of dental foundation training will now be called 'Dental Core Training Posts'.

In the new NHS Performers List Regulations (England) the term 'Dental Foundation Training' has been substituted for 'Dental Vocational Training'. From 1 April this year, dentists will complete a year of dental foundation training (or equivalent period of part time employment) leading to the award of a Dental Foundation Training Certificate to be able to work in the NHS. Posts starting from this summer will adopt the new title of 'Dental Core Training' (DCT) posts.

http://copdend.org/content.aspx?Group=press releasesctPage $=$ press release april 2013

\section{'BIONIC' TEETH MAY FILL GAPS}

Research led by Professor Paul Sharpe ${ }^{1}$ of King's

College London has demonstrated the use of gingival cells to generate bioengineered teeth. By isolating human gingival tissue and combining epithelial cells with embryonic tooth mesenchymal cells from mice, researchers were able to grow hybrid teeth containing dentine and enamel with developing roots. This hybrid tooth potentially offers advantages over current implant-based methods of replacing teeth, which can result in jaw bone resorption since a lack of natural root structure leaves implants vulnerable to the non-buffered forces of chewing.

Meanwhile researchers at the University of Michigan are preparing for the first known human trial to use very small embryonic-like (VSEL) stem cells collected from adults to grow bone. With VSEL stem cells derived from adults instead of foetuses

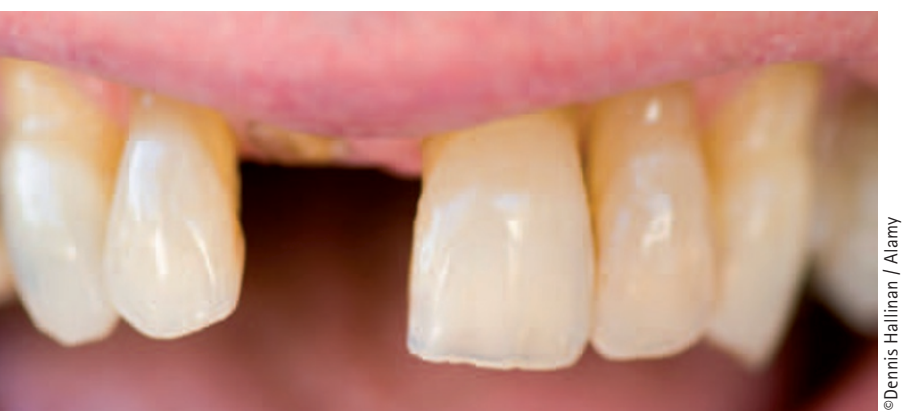

this new method could provide a minimally invasive way to accelerate painful bone regeneration for dental patients. VSEL stem cells are harvested from test patients in need of extraction and dental implantation preexodontia. Pure populations of VSEL stem cells are then inserted back into test patients in between extraction and implant placement to see if VSEL stem cells can reduce healing time and produce better quality bone. When new bone grows, researchers remove a small portion to study and replace it with an implant. This trial will test how concentrated quantities of VSEL stem cells can be developed to treat a wide range of diseases.

- Angelova Volponi A, Kawasaki M, Sharpe P T. Adult human gingival epithelial cells as a source for whole-tooth bioengineering. J Dent Res 2013: 92: 329-334.

2. University of Michigan News Service. Cells culled from adults may grow human bone. Michigan: University of Michigan, 2013.

By Laura Pacey

\section{HANCOCKS PROVIDES} FOOD FOR THOUGHT

In February BDJ Editor-in-chief Stephen Hancocks visited the University of Birmingham to talk on 'How to publish' during one of the dental school's regular Science, Munch and Lunch sessions.

In the course of the presentation Stephen gave his views and advice to the Birmingham audience on such topics as: what journal editors are looking for, how to prepare manuscripts for submission, tips on scientific writing, and how to choose the right publication.

Dr Damien Walmsley, Professor of Restorative Dentistry at the University of Birmingham, pronounced the talk 'well received and our students found it very useful'.

If you are interested in someone from the $B D J$ Editorial Team coming to speak at your university to provide advice on getting your research published, please contact the $B D J$ Managing Editor, Ruth Doherty at r.doherty@nature.com to arrange a visit.

\section{DENTAL GUIDANCE PUBLISHED FOR ALL HEALTHCARE SETTINGS}

The Scottish Dental Clinical Effectiveness Programme (SDCEP) has launched guidance on Management of acute dental problems. The guidance, available in three formats, encourages consistent provision of safe and effective care, on an individual basis, to patients with acute dental problems. It is intended for use in any healthcare setting by staff who may be asked to advise or manage patients with acute dental problems. This includes non-dental professionals, such as general medical practice, emergency department and pharmacy staff, as well as members of the dental team.

The guidance is available via the SDCEP website at www.sdcep. org.uk. 